\title{
MODELS OF ADMINISTRATIVE AND LEGAL REGULATION OF SPONSORSHIP AND PATRONAGE IN THE EU
}

\author{
Iryna Antoshyna ${ }^{1}$, Alina Bondarenko²
}

\begin{abstract}
Today, patronage is the key source of non-governmental support of the socio-cultural advancement of the state because, as the world's practice shows, the state funding is often not enough for conserving and developing the national and cultural heritage. Across the world and Europe, increasing attention is paid to the traditions of charity, corporate philanthropy is in progress, and business ethics are growing. In developed countries, the pursuit of charity activity is caused by a high level of social responsibility of business entities. Both large corporations and wealthy people establish charitable funds or provide a good deal of money for relevant purposes. The problems of patronage or sponsorship as means for guaranteeing the realization of socio-cultural programmes, research initiatives and continual activity of not-for-profit organizations are topical and need an extension study in terms of conditions and prospects for the development. The purpose of the article is the analysis of the experience of administrative regulation of patronage and sponsorship in different countries and its growth potential in Ukraine in the context of international integration and scientific and technological progress. The situation is complicated by the fact that this regulatory scope has originated more recently in the world's practice, and many problems remain unsettled. For example, let's consider some forms of financial rewards used in the rest of the world. In the developed countries, there are models of cooperation with a private fund in the social, cultural, academic and other spheres of social life. They are as follows: the state as a leader; private fund as a leader; partnership and functional division of labour between the state and capital. In social practices, they usually co-exist with a dominant one of them. The first model prevails in France and Italy, the second - in the USA, the third - in the Federal Republic of Germany. Recently, there has been a gradual transition to the third model, which will become dominant in Western countries. Compared to Western Europe, there has been no moral rehabilitation of wealth in Ukraine, which has affected the motivation of charity. It is noteworthy that in the last decade, especially in European countries, state and state-social funds, which are financed using budget funds and the contributions of patrons, have been created. In general, analyzing various forms of patronage and sponsorship in the field of culture of the countries of the European region, it can be argued that in modern Western countries there is a sweeping trend to decrease direct state support of culture by indirect. The attraction of funds of entrepreneurs and non-governmental organizations in various forms is purposefully stimulated by state cultural policy, laws on patronage. In Ukraine, state intervention in the charity area is minimal. It is limited to the statutory regulation of charity activity, registration and accounting of charity organizations. At the same time, some specific normalization of patronage and sponsorship is next to none because it is distinguished among other charity activities mostly by patrons, sponsors, and mass media.
\end{abstract}

Key words: sponsorship, administration model, legal regulation, private fund, art market, social development.

JEL Classification: M14, J24, D30, H70

\section{Introduction}

Today, patronageis thekeysource ofnon-governmental support of the socio-cultural advancement of the state because, as the world's practice shows, the state funding is often not enough for conserving and developing the national and cultural heritage.

Across the world and Europe, increasing attention is paid to the traditions of charity, corporate philanthropy is in progress, and business ethics are growing. In developed countries, the pursuit of charity activity is caused by a high level of social responsibility of business entities. Both large corporations and wealthy people establish charitable funds or provide a good deal of money for relevant purposes. Thus, Warren Edward Buffett, one of the most successful magnates in the world, transferred more than \$ 30 billion in the Bill \& Melinda Gates Foundation.

\footnotetext{
Corresponding author:

${ }^{1}$ National University «Odessa Law Academy», Ukraine.

E-mail: irinavivalmarine@gmail.com

ORCID: https://orcid.org/0000-0002-5950-9907

${ }^{2}$ National University «Odessa Law Academy», Ukraine.

E-mail: alinabon1712@gmail.com
} 
Conservation and development of Ukrainian culture and art, the issues of culture and education remain the priorities of the state policy, and their implementation is interfered by the lack of proper legal regulation, facilitating mechanism, and underfinancing (as a residual). Endeavours for resolving the above problems are carried out at the different levels, in particular by the non-governmental organisations, public communities, private entrepreneurs, philanthropists and sponsors.

The problems of patronage or sponsorship as means for guaranteeing the realization of socio-cultural programmes, research initiatives and continual activity of not-for-profit organizations are topical and need an extension study in terms of conditions and prospects for the development.

The purpose of the article is the analysis of the experience of administrative regulation of patronage and sponsorship in different countries and its growth potential in Ukraine in the context of international integration and scientific and technological progress.

\section{Establishment and development of the institution of charity and patronage}

The contemporary concept of charity has a broad meaning (from a common financial aid to patronage and sponsorship), which involves both high moral values and public awareness of the need to implement social rehabilitation programs for the population categories who request help (Slaboshpytskyi, 2001).

Traditions, which have been formed over the years, have not lost their significance till the present day when it is extremely urgent to improve the functions of government agencies that will conduct an effective regulation of patronage and sponsorship. On the one hand, government authorities should turn their activities to the creation of conditions and promotion of public respect for patrons, philanthropists, sponsors that they chose civilized methods of activities and boost their financial resources be fair and legal means; on the other hand - support their drives to improve the society they live in, in particular through charity, patronage and sponsorship.

The government regulation is a system of measures of legislative, executive and control nature, which are exercised by relevant state bodies and non-governmental organisations for settling and adjusting of the available system to the dynamic environment (Demeshko, 2018).

In order to improve public relations in the area of public administration of patronage and sponsorship, ones apply the methods of legal regulation through which executive bodies carry out actions in public management.

Legal regulation is a method of public administration that has a legal impact on the social and legal aspects regarding charity and its specific elements in the process of harmonising social relations (Pasichnyk, 2005).
Government regulation of patronage and sponsorship is characterized by normalizing relations between the state and patrons through the use of economic controls, development of the moral factor of charity and norms of legal social responsibility, as well as the stimulation of legal functioning of patrons and sponsors.

Thus, in the last decade of the XX century, given the dramatic economic changes which caused the formation of private funds and, as a consequence, the stratification of the population, the issue of charity in Ukraine has become relevant again. For this very reason, the issue of administrative regulation of the development and activities of the charity organisations belonging to the so-called third, non-profit, sector is critically important and problematic for Ukraine.

Exclusively public, commercial and non-profit sectors can together ensure the existence of a stable, democratic and rule-of-law state and civil society.

Majority of modern philanthropists, patrons and sponsors with moral persuasions also calculate both the amount of tax cuts and the public and commercial effect of their charitable actions.

\section{Formation of administrative regulation of corporate sponsorship in Ukraine based on comparative analysis}

Modern Ukrainian entrepreneurship is characterized by the continuation of Ukrainian patronage traditions, which have been based on secret, non-official charity "from hand to hand"; moreover, at the current stage, Ukrainian legislation hasn't developed a system of tax benefits for philanthropists, patrons and sponsors (Demeshko, 2018).

Ukrainian legislation, which regulates the forms of non-governmental support of the development of culture, arts, science and education, is marked, on the one hand, by legislative acts of different level and lack of consistency between the acts and, on the other hand, - by non-conformity of legal norms with needs of participants of legal relations.

The situation is complicated by the fact that this regulatory scope has originated more recently in the world's practice, and many problems remain unsettled. For example, let's consider some forms of financial rewards used in foreign countries:

- the UK doesn't have limits on the amount of charity benefits - companies can channel up to $100 \%$ of their income to charitable contributions without paying income tax; in the case of a donation in cash, the taxpayer may receive a refund of the balance between the basic and maximum income tax rates from the budget calculated for the donation amount; in the case of non-monetary donations, taxable income is reduced by the market value of such donations;

- in the USA, the amount of charity benefits - up to $10 \%$ of company revenue; for cash donations, one can 
receive tax deduction within $50 \%$ of annual revenue and 20-30\% - for non-monetary donations (Tulchynskii, Shekova, 2007).

In the context of research line, the Law of Ukraine "On Charity Work and Charity Organizations" dated July 5, 2012, No 5073-VI belongs to the fundamental legislative acts specifically adopted for the regulation of charity process. According to the above law, one of the forms of charity activity is patronage, which is a philanthropic activity in education, culture and arts, cultural heritage conservation, science and research conducted in the way established by the law under consideration and other laws of Ukraine (Zakon Ukrainy "Pro blahodiinu diialnist ta blahodiini orhanizatsii", 2012).

Part 1 Art. 10 of the Law marks that patronage is the preparation or support of charitable events related to the creation, reproduction or use of pieces and other objects of intellectual property as prescribed by law, including charitable touring activity providing free access (Zakon Ukrainy "Pro blahodiinu diialnist ta blahodiini orhanizatsii", 2012).

It doesn't involve initiatives associated with the advertisement (except PSA), election campaigning as well as the presentation or use of commercial (brand) names, trademarks (marks for goods and services) and industrial designs protected as required by law.

However, the Law doesn't provide any tax and other benefits, but it proclaims their provision. Specific forms of moral incentives are not included, and those individuals and legal entities that carry out charity without mediation, that is, private sponsors and patrons, don't gain substantial motivation.

Ineffective and non-purpose use of patronage funding is a major problem. To resolve the problem, it is necessary to establish a special patronage commission empowered with the functions towards determining the recipient of patronage support, priority social sectors to provide patronage assistance in the implementation of social policy, coordination of patrons activity, registration of the contract between the benefactor and beneficiaries, control over the proper fulfillment of contractual obligations between the benefactors and beneficiaries, protection of legal rights and interests of benefactors and beneficiaries.

In 2017, it was promulgated two Bills of Ukraine on a narrower focus - "On Patronage in Physical Education and Sports" dated July 19, 2017, No 6770 and "On Patronage in Physical Education and Sports" dated August 1, 2017, No 6770-1, (Proekt Zakonu Ukrainy "Pro metsenatstvo u sferi fizychnoi kultury ta sportu", 2017). Explanatory notes to the Bills don't present satisfactory arguments, which would call for the adoption of an individual legislative act on patronage in physical culture and sports. For this very reason, Head Office for Research and Evaluation of the Verkhovna Rada of Ukraine expressed some comments on both bills and marked that best practices contained in the bills can be drawn up in the form of alterations and amendments to the current legislation of Ukraine regulating the relevant social relations, in particular: the Laws of Ukraine "On Charity Work and Charity Organizations", "On Advertising" and "On Physical Education and Sports".

Government intervention in charity is minimal in Ukraine. It is limited to the statutory regulation of charity activity, registration and accounting of charity organizations. At the same time, some specific normalization of patronage and sponsorship is next to none because it is distinguished among other charity activities mostly by patrons, sponsors, and mass media.

\section{Interaction models of private funding with the social sectors}

In the developed countries, there are models of cooperation with a private fund in the social, cultural, academic and other spheres of social life. They are as follows: the state as a leader; private fund as a leader; partnership and functional division of labour between the state and capital. In social practices, they usually co-exist with a dominant one of them. The first model prevails in France and Italy, the second - in the USA, the third - in the Federal Republic of Germany. However, recently there has been a gradual transition to the third model that obviously will be dominant in the Western world (Demeshko, 2018). The activity of J.M. Keynes, mathematics and economist, is an example of charity and patronage in Europe in the early XX century. Due to J.M. Keynes, charity and patronage are the most important features of the image of most European companies and firms.

Americans had had the feeling of social responsibility, the desire of helping people long before the USA advent. The deduction of tax donations, which was introduced by Abraham Lincoln, was an impetus for patronage, especially among wealthy people. But at that time it was just a short-run measure, it became permanent in the XX century. Andrew Carnegie laid the foundation for modern American patronage. He believed that wealthy people should spend their money during life and die poor because it is a shame to die rich (Baumol, Bowen, 1966). John Rockefeller, who founded a giant charity fund in 1891, heeded Carnegie's advice. After World War I, the U.S. Congress adopted a law on tax relief for philanthropists, who donate to charity, for supporting economic growth. In 1921, donations in the USA totaled \$ 1 billion 700 million. There are now about a million tax-exempt charity organizations. Religious services obtain most donations $-35 \%$, and universities, colleges, private schools $-14 \%$, etc. (Sirotin, 2005). The U.S. state system rewards those who run philanthropy and make charity economically sound. The basic motive of interest in patronage in the USA is the ability of tax deduction for charitable donations. Over the last 
40 years, the amount of annual donations has reached two percent of the country's gross domestic product. In 1990, U.S. citizens donated $\$ 111.5$ billion to charity and \$ 151 billion in 1996 (Yurchenko, 2016).

Unlike Western Europe, there was no moral rehabilitation of wealth in Ukraine that affected the motivation of charity. Charity activity in Ukraine was based exclusively on moral and ethical principles. Moreover, Ukraine's entrepreneurial background had social nature mainly composed not of urban citizens but peasants who had gained freedom due to the abolition of serfdom. At the moment, when solving the problem of optimization of the socio-cultural sphere, Ukrainian theorists often reach out to the national charity mentality and strong Ukrainian tradition of entrepreneurial charity and philanthropy, which was formed in the XIX century. The lack of similar mental prerequisites also explains the unsatisfactory situation of charity and patronage in contemporary Ukraine. It is significant that in the last decade, especially in European countries, state and state-social funds have been established financed by the budget and the contributions of patrons. In Western Europe and the USA, about a third of social programs are implemented by private charitable foundations, which accumulate significant funds of patrons. According to the statistics, in the USA, it was registered about 40 thousand such organizations, and in Europe, their number ranges from 80 to 100 thousand (Shveda, 2018).

Tax benefits are a key reason for the worldwide prevalence of charity funds, particularly corporate ones. The legislation of many countries allows the use of income share of business entities for charitable purposes instead of paying the relevant taxes. The arguments through the government prism are obvious: charity funds contribute to the financing of social programs and projects, that is, partly take on the role of government authorities: the assistance to disabled people, low-income individuals, and the work with children and youth, education of citizens. American financier George Soros was known to the world, not due to the results of his business activity but the network of his charity funds that is represented in Ukraine by the International Renaissance Foundation and many other charity organizations.

The legislation of most developed countries stipulates that the amount of charitable contributions is deducted from the income of the patron (taxpayer) before it reaches the area of profit control.

The U.S. legislation is developed in such a way as to promote any kind of charity activity regardless of its focus. The state acts as the central regulator of financial relations, which it uses as a motivation for philanthropic efforts, in particular, patronage. At the same time, the prevalence of private initiatives is conditioned by the stimulation at all levels. It became an element of psychology, which is manifested in politics speech:
"I applaud any organization that proves what private charity can do without state mandates or interference" (Congressman Ron Paul, 14th District of Texas, 1962).

Thus, afterWorldWarI, the U.S. Congress adopted a law on tax relief for benefactors-enterprises for supporting economic growth. In 1921, donations in the USA totaled $\$ 1$ billion 700 million, and the amount of annual donations significantly increased to over $\$ 200$ billion at the end of the XX century (Number of Public Charities in the United States, 2010). By 2018, there were about one million tax-exempt charitable organizations in the country. Private charity organizations are a premier source of financing science, arts and culture in the USA. However, there is the National Foundation on the Arts and the Humanities, which coordinates affairs in the area under consideration (Demeshko, 2018).

That kind of policy enables citizens to define an area of charity, which is the most interesting for them, independently. As for philanthropy in the narrower sense, the traditional concept of assisting artists and cultural representatives, the system (according to statistics for 2010) allowed it to be third in the ranking of philanthropic efforts.

According to the National Centre for Charitable Statistics (NCCS), charity initiatives in arts, culture and humanities are inferior to educational programmes and religion-based charity (Number of Public Charities in the United States, 2010). If one considers patronage more broadly, combining the development of culture, art and education, it is the dominant form of charity.

In the United States of America, patronage (both charity and philanthropy) in art in the XX century reached the character of a national tradition based on the mentality of that component of the upper social class, which belongs to the business community. Apart from the altruistic motives and mercenary interests related to the features of the U.S. tax system beneficial to philanthropists, the prestige aspect plays an important role in the area concerned.

The philanthropist, who is a funder for non-profit creative organizations or projects, in such a way manifests his affiliation with the elite community. In accordance with American charity traditions, the participation in philanthropic activities in arts, membership in the board of directors or trustees of non-profit creative organizations, providing them with financial, organizational and other assistance is a characteristic that determines the affiliation of a benefactor with the upper social class in the public eye, confirmation of a subtle aesthetic sense, class and intellectualism. At the same time, mass media plays a big part in covering that sort of positioning for a wide audience (United Nations Global Compact, 2017).

It is also worth mentioning that in the USA, the government support for culture is represented in the form of grants, not subsidies. The core funding is ensured by sponsorship and the philanthropy 
mechanism. The state creates conditions for effective interaction of business with culture. Own income (revenue from ticket sales, advertising, contributions of members of professional associations, etc.) is provided by American cultural organizations with the necessary funds by approximately $55 \%$, another $25 \%$ of budgets are generated through grants from private and corporate funds, donations from individuals and companies, $12 \%$ give investments in securities, and about $9 \%$ of expenses are covered by the public sector (Analytics, 2017). This is the most liberal model. Here the culture is developed based on the private initiatives, and the state plays an indirect, supplementary role, in particular, provides various tax benefits and actively uses administrative resources to encourage private initiatives and philanthropists. As a result, the amount of charitable contributions in the USA is very large: in 2018, about \$ 200 billion was donated within the country, and $75.6 \%$ is the contributions of individuals (Demeshko, 2018).

In the UK, the state acts as a patron. It is remote from culture and has no ownership of cultural institutions, distributes government subsidies through parastatal, quasi-public non-profit organizations. The UK has pioneered the use of a variety of Public-Private Partnership mechanisms in the field of culture known as "Private Finance Initiative". Public-Private Partnership means that the state is responsible for project assurance and the responsibility for its financing and implementation is allocated between private business and non-governmental organisations (Sofiyenko, 2012).

In 2003, France developed the tax system which offers $60 \%$ reduction in taxes for corporates, if they provide patronage assistance. Thus, in France, until the middle 1980s, the state was the only source of culture funding, but the needs of the latter were covered by $30 \%$. As a result, it was elaborated new forms of culture funding, which are based on the complete revision of the relationship between the cultural sector and business world, the all-round encouragement of industrial philanthropy which leads to the fundraising of large enterprises in the non-profit sector. Patronage organizations began to emerge in the country, and the High Patronage Council was formed whose key task is to establish cooperation between the state and business for the implementation of cultural programs. Most European countries have national sponsor associations that regulate the relationship between sponsors and beneficiary institutions. ADMICAL (Association for the Promotion of Trade and Industrial Patronage), which coordinates the private and public activities of entrepreneurs to support and contribute to the culture, plays that sort of role in France (Tulchynskii, Shekova, 2007). Increasing interest in industrial philanthropy is one of the aspects of a more general tendency in the cultural life of French society - the decentralization of cultural activity which has become relevant in modern Ukraine. In France, an enterprise may be engaged either within the framework of the special fund or their institutions, which focus towards the public (for example, the fund of French company "Gaz de France"). The head motive of business patronage is to create a positive image of the company, but not to advertise their production or ensure sales growth.

The country also has large non-governmental foundations, in particular, French Fund, Institut de France etc., which support the establishment of the socalled "satellite funds" where the assets of an enterprise are accumulated. Subsequently, French Fund or Institut de France uses the assets to conduct an event in agreement with the donor company. Another type of French philanthropy has a centennial timeline and is associated with the assistance to modern talented writers (literary awards). France has about 3 thousand different literary awards. The most prestigious are French Academy Award, Prix Goncourt, Prix Femina, Prix Médicis, Internals, Kléber Edens, Novembre, etc. (Demeshko, 2018).

In modern Italy, the concepts "patronage" and "sponsorship" are considered to be nearly similar. However, in recent times, sponsorship has been prioritized. In terms of culture, the phenomenon became widespread in the 1980s. Its influence was specifically significant in sports, which in Italy belongs to the cultural sector. Other spheres are also covered. It is confirmed by two laws on tax exemptions in culture sponsorship which were adopted in the 1980s.

They significantly promote the involvement of private funds in the cultural sector. The 1982 Law provides for unlimited cost reductions on restoration and preservation of historic monuments and cultural facilities as well as the financing of various exhibitions. The 1985 Law reduces the amount of tax payment for music, theater and cine products received as a gift, as well as for capital investments in the theaters and cinemas restoration, with a limit of $2 \%$ of annual income. At the same time, Italy has some difficulties related to patronage and charity.

One of the key problems is the lack of considerable coordination between the state and private sponsors. The matter is that private entrepreneurs are not aimed at caring the public welfare but at the maximum benefit of all the initiatives for culture sponsorship. For this reason, businesses are competing for the right to invest in the most prestigious monuments, exhibitions, while creativity areas remain in the background (Volkov, Korniichuk, 2008).

In Italy, only government and private organizations, which have the government's confidence, can donate to exhibitions organization, acquisitions and restoration of artistic values. Greece permits allocating 30\% to patronage and German - 33.2\% (Demeshko, 2018).

The study of the model of administrative regulation of charity, philanthropy and sponsorship in modern Germany is of great scientific interest, since its 
development has been going on for many decades, and the results achieved by Germany in the area concerned can be taken into account in the arrangement of charity activities in other countries of the world, including Ukraine.

In 1962, Germany introduced social care (Sozialhilfe). 500 thousand people, $1 \%$ of the population, were beneficiaries of different grants-in-aid and assistance. In the last decade, the goal of social care is to promote the achievement of a decent standard of living for the beneficiaries (it includes providing a person with food, shelter, clothing, hygienic means, household goods, as well as enabling him/her to participate fully in cultural life). Care assistance should contribute to the beneficiary's acquisition of financial independence, and he/she is obliged to facilitate it according to his/her efforts.

In the 1970s of the XX century, Germany carried out a wide-scale reform of social legislation. Since 2001, the framework law is "Federal Act on the Granting of Social Assistance” (Bundessozialhilfegesetz), which regulates the right and duties both of social care receivers and welfare service as well as types of assistance and relationships of the mentioned service with others. As from 1975, it was used 10 Books of Social Codes (Sozialgesetzbuch) governing different legal situations and procedures. It is necessary to point out that "German Reunification Treaty" (Einigungsvertrag) stipulates special circumstances for new lands (except Berlin) by which operation of the provisions set out in the Book of Social Codes is limited by available funds: lack of funds at the municipal budget of any of the new lands causes the payment of social assistance in a reduced form (Demeshko, 2018). According to the current legislation, the national social service (Sozialamt) is obliged to assist any person who seeks the help provided that he/ she is registered in Germany. Therefore, the following categories of citizens may be the beneficiary of charity that is non-state social assistance:

- people who do not have a registered place of residence (homeless people). There are about 30,000 of them in the country per 82 million of the population;

- receivers of the government social assistance during settling an apartment. They are favored in the purchase of furniture, electrical appliances (cooker, refrigerator, washing machine, vacuum cleaner, TV); it is paid only pre-owned stuff dealt through buying up or bought at the warehouses of charity organizations;

- people who were rejected in assistance by the government social services for any reason, or people who need urgent aid. Therefore, in German, the representatives of the abovementioned demographic groups compose a theoretical Register of Potential Beneficiaries. Charity organizations keep a register of people secured assistance (Shveda, 2018).

Five subjects are the most significance for the charity activityin themodern Germany, and threeofthemarelarge non-governmental organisations - Arbeiterwohlfart, Caritas, Diakonisches Werk (Analytics, 2017). As it proceeds from the above, the policy objectives of the first organisation (Arbeiterwohlfart) is charitable assistance for workers and their family members, other two help people in need according to their confession. The latter two subjects comprise charity funds and volunteering activities.

In the activities of charity funds, it is essential to draw attention to the mechanism of generating and spending the funding, in particular, the use of interest on capital assets for charitable purpose but not the capital itself. The volunteering activities are characterized by the active participation of senior citizens.

The experience of foreign countries has shown that the involvement of private fund in the philanthropic financing of arts and culture is not a spontaneous process but regulated by state policy, which is based on system scientific research of charity issue. The legislation of foreign countries demonstrates its effectiveness in practice since it stipulates the following: the amount of charitable contributions is deducted from the income of the benefactor - the taxpayer even before that income gets into the area of profit control. Taking into account the positive nature of the above experience, Ukraine should develop national fundamentals of charity and charitable activities which will be consolidated at the legislative level nationwide.

\section{Key trends of the development of the global art market}

According to the data of benchmark reports of The Art Market prepared by Arts Economics through the request of Swiss bank UBS and the international art fair Art Basel, the volume of the global art market was \$ 63.7 billion in 2017 that is up by $12 \%$ than in 2016 . It is worth noting that the market started to grow after two years of decline (-7\% in 2015 and $-11 \%$ in 2016), despite political risks and the continued slowdown in the global economy. However, the current rate is lower than historical peak in 2014 ( $\$ 68.2$ billion). The dynamics of the global art market in 2016-2017 are represented at Figure 1 (Analytics, 2017), Arts Economics and Art Basel, 2019).

In general, the return of market growth was possible due to the increased sales in the post-war and contemporary art segments, positive dynamics in Asian markets, and soaring sales of the Old Masters' segment. In this context, it should be pointed out that sales in the segment of top-priced artworks (over \$ 1 million) accounted for more than $50 \%$ of total sales and less than $2 \%$ of all transactions.

Thus, the sale of Leonardo da Vinci's Salvator Mundi, which was brought to the hammer at Christie's in 2017 for \$ 450 million, set a record in sales. Among examples of million-plus items in 2018, there is a painting "Masterpiece" of Roy Lichtenstein, an American pop artist, which was sold for \$ 165 million. That sort of 


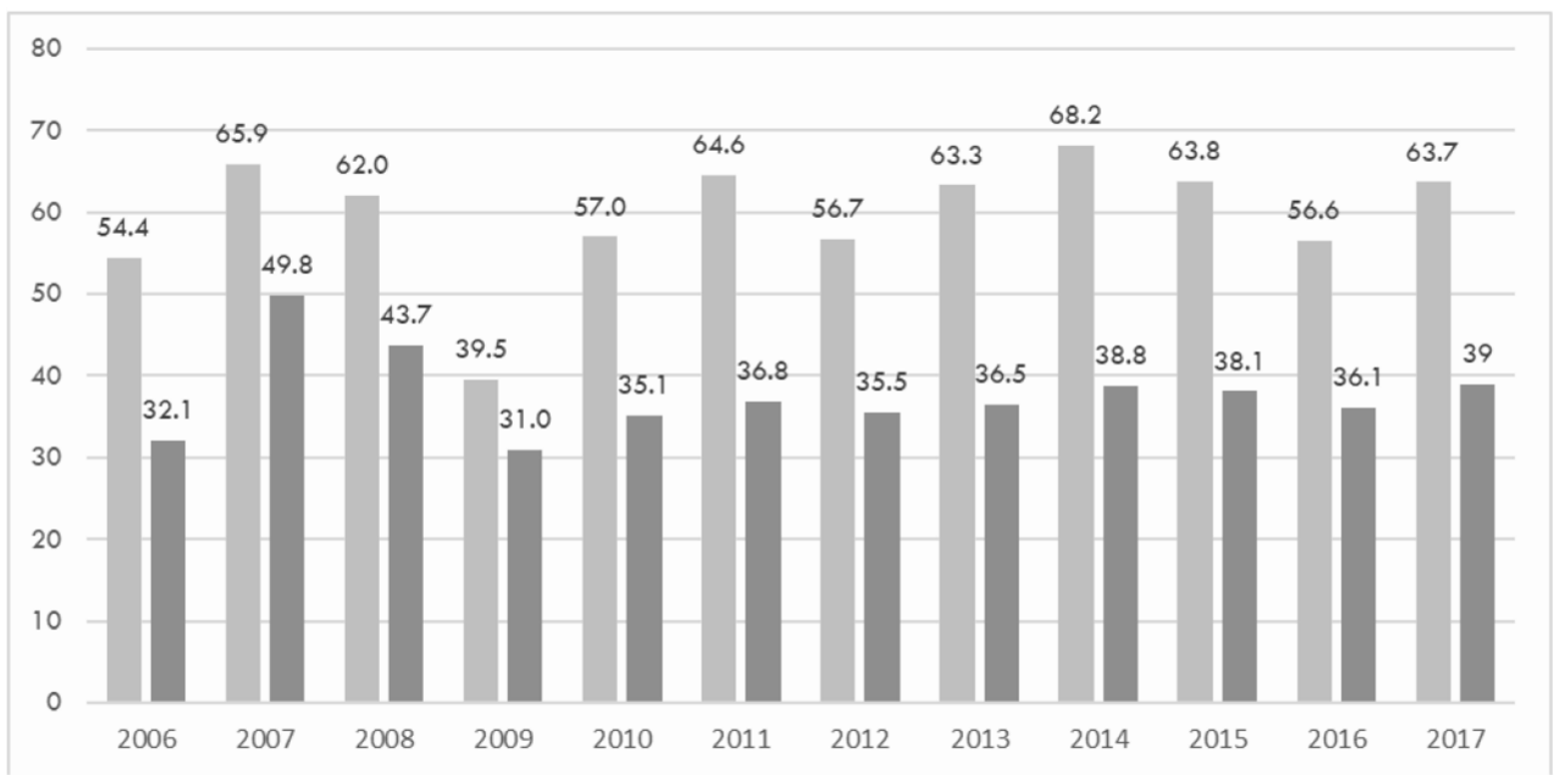

Figure 1. The dynamics of the global art market in 2006-2017

1 column - volume of the global art market (billion dollars)

2 column - number of transactions (million pieces)

Source: Arts Economics and Art Basel, 2019

situation is typical for art market (Arts Economics and Art Basel, 2019).

After analyzing the results of studies of the contemporary art market, one can identify some trends that are specific to this creative area. In particular, it is observed the following processes:

1. Globalisation and decentralization of the art market. The unification of ways for regulating relations between sellers and buyers gradually takes place. Art fairs are held around the world, not just in key cultural centers. There is an increase in the mobility of all participants in the art market. Moreover, state support is prominent in this case. Thus, for example, the government has contributed to a tremendous upgrowth of the Chinese art market.

UAE doled out $\$ 1$ billion to create world-class museums of contemporary art. Morocco and Oman also allocate funds for the construction of museums. Qatar actively buys pieces of the acknowledge masters by auctions. However, "traditional" states-players (USA, Western European countries) still have a major impact on the market. Moreover, due to the limits established by the government of some countries, a specific list of masterpieces can't be exported outside national borders.

2. Art market digitalization. According to the data of analytical agencies, there has been a significant increase in the rate of online art sales in the world over recent years - it accounted for $8.4 \%$ of the global art market (+ $14 \%$ on 2016 level) in 2017. In 2019, the figure was down to $6.6 \%$, but it is caused by the market growth due to the sale of million-plus items through the traditional bidding (Arts Economics and Art Basel, 2019).
There is a rapid growth among specialized electronic trading platforms, which were also created in partnership with the world's leading auction houses. Using blockchain technology, it is expected to solve a key problem in the art market related to transaction transparency and items authenticity. The style of digital arts has been originated and is actively developing in which approaches non-traditional for the art market can be used (for example, advertising in the social media account of a digital designer etc.)

3. Fusion of different creative areas (design, fashion, computer games etc.). Today, major fashion houses and designers actively collaborate with contemporary artists, engaging them to create collections and objets d'art, organize art events. For example, such exhibitions as Beauté Congo presented at the Fondation Cartier (2015) or Art/Afrique at the Fondation Louis Vuitton (2017) were designed to support creative activities of African artists. Fashion houses also establish own museums: for example, Punta Della Dogana belongs to Gucci and Christie's. Computer games segment, which constantly requires a high-quality and extraordinary design, is booming.

4. Change of the key business-models on the market. Auction houses have begun to conclude many private agreements not only within the framework of the art institutes but also through buying art galleries. Thus, Sotheby's bought a Dutch gallery Noortman Master Painting focused on the Old Masters' pieces in 2006. Today, auction houses compose $40 \%$ of sources of art objects for resale to art dealers (Arts Economics and Art Basel, 2019). 
5. Despite a specific nature of the industry, art markets center around the customization of services provided. Thus, for example, Sotheby's acquired information and technologic assets in wholesale numbers in 2016-2017. In particular, the auction house bought:

- an advisory firm Art Agency, Partners for a large address database of potential clients;

- Mei Moses Indices which make it possible to estimate an investment attractiveness of some goods and artists. Now they are called Sotheby's Mei Moses;

- an American start-up Thread Genius, which identify artistic objects and then recommend some objects which satisfy the buyer's mind and budget (Arts Economics and Art Basel, 2019).

6. Auction houses also carry out charitable educational activities mainly intended to teach collectors. The main objective of that kind of policy is to "bring up" a loyal audience.

7. Promotion of the availability of art objects. According to the data of analytical agencies, in most countries around the world, the middle class is gradually transiting from intellectual consumption of art (contemplating exhibit items in museums, reading arts books on art, etc.) to buying or renting it, including modern art. In the estimation of Skate's, the segment of available art for charity or sponsorship is currently about $25 \%$ of the global art market (Arts Economics and Art Basel, 2019).

Confirmation of the fact that the above is a powerful trend is the strategic reorientation of the world's largest auction house Christie's. Nowadays, it is focused upon the service geared towards the potentials of the middle class and online sale of art items of any price range. Sotheby's target audience remains the same - UHNWI and HNWI.

8. The emergence of modern tools for renting and leasing of art pieces whose use is gradually becoming a global trend. Moreover, the rental cost is moderate (for example, from 10\% of the official value of the item per month in the USA, or $10-15 \mathrm{~L}$ per month in the UK). Any legal or natural person can become a tenant of an art object. Due to the promotion of new financial models in arts, there is a worldwide practice of art index institutes, which have the right to carry out renting and leasing operations at the legislative level including some related services (insurance, transportation of art objects, etc.), has become popular (Arts Economics and Art Basel, 2019).

\section{Conclusions}

In Western countries, the state actively supports the development of charity and patronage by creating favorable conditions. Belgium and the UK provide incentives for sponsorship through deducting the amount spent on advertising and marketing from the taxable value. In Austria and France, sponsorship is interpreted is as marketing expenses of a company for non-taxable advertising.

The U.S. legislation is developed in such a way as to promote any kind of charity activity regardless of its focus. The state acts as the central regulator of financial relations, which it uses as a motivation for philanthropic efforts, in particular, patronage. At the same time, the prevalence of private initiatives is conditioned by the stimulation at all levels.

In general, analyzing various forms of patronage and sponsorship in the cultural sector of the countries of the European region, it can be argued that in modern Western countries there is a sweeping trend to decrease direct state support of culture by indirect. The attraction of funds of entrepreneurs and non-governmental organizations in various forms is purposefully stimulated by state cultural policy, laws on patronage.

In Ukraine, state intervention in the charity area is minimal. It is limited to the statutory regulation of charity activity, registration and accounting of charity organizations. At the same time, some specific normalization of patronage and sponsorship is next to none because it is distinguished among other philanthropic activities mostly by patrons, sponsors, mass media, experts of non-governmental organizations and people affiliated with a charity.

In our opinion, the current Law of Ukraine "On Charity Work and Charity Organizations" has some deficiencies: - it doesn't define the concept of tax exemption for patrons because a patron has already contributed personal funds to perform tasks of nationwide scale; - there are no moral incentives for patrons;

- it doesn't include social incentives for the development of patron activities;

- it doesn't cover the issue of division of powers that is extremely important in the context of administrative reform targets etc.

Thus, the strategic goal of the development of Ukrainian society and the need for a system approach to the legal regulation of cultural activities, the lack of budget financing, as well as the existing gaps in the current branch legislation cause the need to govern certain issues in an individual legal act.

The Law of Ukraine "On Patronage" would promote the development of culture, art, education and science under the conditions of an inadequate level of patronage in Ukraine. To advance patron activity and its encouragement on the part of the state, in particular for the assignment of tax benefits, it is required the legislative consolidation of the institute through amending the Law of Ukraine "On Charity Work and Charity Organizations” dated July 5, 2012 № 5073-VI (Zakon Ukrainy "Pro blahodiinu diialnist ta blahodiini orhanizatsii", 2012).

Ukrainian legislation regulating the mentioned relations has been improved over recent decades. However, there is no consistent differentiation by 
incorporation forms and operation targets of such organizations. None legislative act currently contains a full list of incorporation forms of the non-profit organization which may operate across the territory of independent Ukraine (Zakon Ukrainy "Pro hromadski obiednannia", 2012).

The world and domestic practice show that it is not enough to have only government support to preserve cultural heritage and enhance the creative, intellectual potential of society. In order to promote patronage, it is necessary to have favorable legal framework, moral and financial assistance of patrons as well as obligatory response to the change of key trends and models forming the markets and running an art business.

After analyzing the results of studies of the contemporary art market, one can identify some trends that are specific to this creative area. In particular, it is observed the following processes: Globalisation and decentralization of the art market. Art market digitalization. Fusion of different creative areas (design, fashion, computer games etc.). Change of the key business-models on the market. Focus on the customization of services provided. Promotion of the availability of art objects and the origin of the segment of charity and sponsor art. The emergence of modern tools for renting and leasing art pieces.

Nowadays, patronage is an important source for the non-governmental support of the socio-cultural development of every country because, as the world's practice shows, it is often not enough to have only government support to preserve and develop national and cultural heritage.

\section{References:}

Arts Econimics и Art Basel (2019). The Art Basel and UBS Global Art Market Report 2019. Retrieved from: https://www.artbasel.com/news/art-market-report

Analytics (2017). Social responsibility of business. Information and analytical material. Retrieved from: http://www.svb.org.ua Baumol, W. J., \& Bowen, W. G. (1966). Performing Arts: the Economic Dilemma. New York: Twentieth Century Fund, $582 \mathrm{p}$.

Congressman Ron Paul, 14th District of Texas (1962). In Praise of Private Charity. United States House of Representatives. Retrieved from: http://paul.house.gov/index.php?option=com_content\&view=article\&id= 1962: in-praise-of-private-charity\&catid=62:texas-straight-talk

Demeshko, M. (2018). Zarubizhnyy dosvid administratyvno-pravovoho rehulyuvannya metsenatstva i sponsorstva [Foreign experience of administrative and legal regulation of patronage and sponsorship]. Naukovyy visnyk publichnoho ta pryvatnoho prava, 6(1), 242-248. (in Ukrainian)

Demeshko, M. (2018). Normatyvno-pravove rehulyuvannya metsenatstva i sponsorstva v Ukrayini [Legal regulation of patronage and sponsorship in Ukraine]. Naukovij visnik Nacionalnoi akademii vnutrisnih sprav, 4(109), 271-284. (in Ukrainian)

Konstytutsiia Ukrainy (1996) vid 28 cherv. 1996 r. No. 254k/96-VR [Constitution of Ukraine from June 28, 1996, No. 254k/96-VR]. Retrieved from: http://zakon5.rada.gov.ua/laws/show/254\%D0\%BA/96-\%D0\%B2\%D $1 \% 80$ (in Ukrainian)

Nakaz Ministerstva finansiv Ukrainy (2013). "Pro zatverdzhennia Polozhennia pro Reiestr neprybutkovykh ustanov ta orhanizatsii": vid 24 sich. 2013 r. No 37 [Order of the Ministry of Finance of Ukraine "On Approval of the Regulation on the Register of Non-Profit Institutions and Organizations" from January 24, 2013, No 37]. Retrieved from: https://zakon.rada.gov.ua/laws/show/z0267-13 (in Ukrainian)

Number of Public Charities in the United States, (2010). Urban Institute, National Centre for Charitable Statistics. Retrieved from: http://nccsdataweb.urban.org/PubApps/profileDrillDown.php?state=US\&rpt=PC

Pasichnyk, M. S. (2005). Istoriia Ukrainy: derzhavnytski protsesy, rozvytok kultury ta politychni perspektyvy [History of Ukraine: state processes, development of culture and political perspectives]. Kyiv: Znannia. (in Ukrainian)

Proekt Zakonu Ukrainy "Pro metsenatstvo u sferi fizychnoi kultury ta sportu" (2017) vid 1 serp. 2017 r. No 6770-1 [Draft Law of Ukraine "About patronage in the field of physical culture and sports" from August 1, 2017, No 6770-1]. Retrieved from: http://search.ligazakon.ua/1_doc2.nsf/link1/JH5821AA.html (in Ukrainian)

Shveda, D. (2018). Dosvid zarubizhnykh k krayin u sferi derzhavnoho rehulyuvannya metsenatskoyi diyalnosti [Experience of foreign countries in the sphere of state regulation of patronage activity]. Retrieved from: http://libfor.com/index.php?newsid=318 (in Ukrainian)

Venglovskiy, A. (2005). Dary svyshe [Gifts from above]. Biznes, 43, 86-90. (in Russian)

Slaboshpytskyi, M. (2001). Ukrainski metsenaty. Narysy $z$ istorii ukrainskoi kultury [Ukrainian philanthropists. Essays on the history of Ukrainian culture]. Kyiv: Yaroslaviv Val. (in Ukrainian)

Sirotin, A. (2005). Metsenatstvo v USA [Patronage in the USA]. Chayka, 2, 2-9. (in Ukrainian)

Smolyak, I. (1996). Blahodiynytstvo vdoma i za rubezhem [Charity at Home and Abroad]. Polityka i chas, 9, 54-57. (in Ukrainian)

Social Responsibility - The Basis of Business Philosophy (2016). Retrieved from: www.svb.org.ua/reviews/ sotsialna-vidpovidalnist-osnova-filosofii-biznesu

Sofiyenko, A.V. (2012). Sotsial'na vidpovidal'nist' biznesu: rozuminnya ta suchasni tendentsiyi [Social responsibility of business: understanding and current trends. Economic innovation]. Ekonomichni innovatsiyi, 47, 297-301. (in Ukrainian) 
Tulchynskii, G. L., \& Shekova, E. L. (2007). Menedjment $v$ sfere kultury [Management in the field of culture] (3rd ed.).SPb.: Lan; Izd-vo planeta muzyki. (in Russian)

United Nations Global Compact (2017). Retrieved from: http://www.unglobalcompact.org./participants/search Volkov, V. V., Korniichuk, V. P., \& Khomiak, K. D. (2008). Stratehichnyi vystavkovyi menedzhment [Strategic exhibition management]. Kyiv: Mizhnar. ekonom. un-t. (in Ukrainian)

Yurchenko, O. (2016). Podatok na mylostynyu [Charity tax]. Visnyk podatkovoyi sluzhby Ukrayiny, 19, 4-7. (in Ukrainian)

Zakon Ukrainy (2012). "Pro blahodiinu diialnist ta blahodiini orhanizatsii": vid 5 lyp. 2012 r. No 5073-VI [Law of Ukraine "About the blessing of that kind of blessing of the organization" from July 5, 2012, No 5073-VI]. Retrieved from: https://zakon.rada.gov.ua/laws/show/5073-17 (in Ukrainian)

Zakon Ukrainy (2012). "Pro hromadski obiednannia": vid 22 berez. 2012 r. No 4572-VI [Law of Ukraine "About a lot of things" from March 13, 2012, No 4572-VI]. Retrieved from: https://zakon.rada.gov.ua/laws/show/4572-17 (in Ukrainian) 